\title{
A dabigatran-antidótum, az intravénás idarucizumab első hazai alkalmazása
}

\author{
Driesz Lajos dr. ${ }^{1}$ - Barabás Éva dr. ${ }^{1}$ - Bodócs Ildikó dr. ${ }^{1}$ \\ Szántó Zoltán dr. ${ }^{1}$ - Herr György dr. ${ }^{1}$ - Bencsik Gábor dr. ${ }^{1}$ \\ Pál László dr. ${ }^{2}$ - Borbola József $\mathrm{dr} .^{3}$ \\ 'Jász-Nagykun-Szolnok Megyei Hetényi Géza Kórház-Rendelőintézet, Szolnok \\ ${ }^{2}$ Boehringer Ingelheim RCV GmbH \& Co KG Magyarországi Fióktelepe, Budapest \\ ${ }^{3}$ Gottsegen György Országos Kardiológiai Intézet, Budapest
}

\begin{abstract}
Az új típusú, direkt orális antikoagulánsok közül jelenleg egyedül a direkt trombingátló dabigatran rendelkezik hatékony antidótummal. Az idarucizumab egy humanizált, monoklonális dabigatrant megkötő antitestfragmentum, amely a gyógyszer szelektív véralvadásgátló hatását azonnal, tartósan, biztonságosan felfüggeszti. A szerzők a dabigatran iv. antidótuma, az idarucizumab első hazai alkalmazását (2016. május 23.) ismertetik egy nonvalvularis paroxysmalis pitvarfibrilláció miatt dabigatrant $(2 \times 110 \mathrm{mg} / \mathrm{nap})$ szedő, akut cholecystectomiára szoruló, magas stroke-rizikójú, csökkent vesefunkciós idős nőbetegen. A beteg a mútét előtt két órával antidótumot (idarucizumab $2 \times 2,5 \mathrm{~g} / 50 \mathrm{ml}$ iv.) kapott, a sebészeti beavatkozás kapcsán kontrollálhatatlan vérzés nem volt. Az antikoaguláns hatásra utaló mútét előtti megnyúlt aktivált parciális tromboplasztinidő az antidótum beadása után normalizálódott. Az idarucizumab iv. beadása kapcsán mellékhatás, szövődmény nem volt. A beteg felgyógyulása után ismét dabigatrankezelést alkalmaztak. Orv. Hetil., 2017, 158(10), 387-392.
\end{abstract}

Kulcsszavak: direkt orális antikoagulánsok, dabigatran, antidótum, idarucizumab

\section{The first use of iv. idarucizumab for dabigatran reversal in Hungary}

At present, the direct thrombin inhibitor dabigatran is the only one amongst the new direct anticoagulants which has an effective, specific reversal agent. The novel agent idarucizumab is a humanized, monoclonal antibody fragment binds to dabigatran within minutes thereby offers an opportunity to induce a safe, long-lasting reverse of the anticoagulant effects of dabigatran. The authors describe the first use of idarucizumab in Hungary (23. 05. 2016) in an old female patient with non-valvular paroxysmal atrial fibrillation of high stroke risk-score and renal dysfunction who was taking dabigatran $(2 \times 110 \mathrm{mg} /$ day $)$ when an acute abdomen developed requiring emergency cholecystectomy. Patient received the antidote (idarucizumab $2 \times 2.5 \mathrm{~g} / 50 \mathrm{ml}$ iv.) two hours before the surgical intervention, and she did not have any uncontrollable, life-threatening bleeding during the surgery. The high activated partial thromboplastin time relating to anticoagulative influence before the surgery normalized completely after administration of the antidote. Antagonizing dabigatran with idarucizumab was feasible and safe without any side effects. The patient received dabigatran therapy again after her recovery.

Keywords: direct oral anticoagulants, dabigatran, antidote, idarucizumab

Driesz, L., Barabás, É., Bodócs, I., Szántó, Z., Herr, Gy., Bencsik, G., Pál, L., Borbola, J. [The first use of iv. idarucizumab for dabigatran reversal in Hungary]. Orv. Hetil., 2017, 158(10), 387-392.

(Beérkezett: 2016. december 9.; elfogadva: 2017. január 13.) 


\section{Rövidítések}

APTI = aktivált parciális tromboplasztinidő; COPD = krónikus obstruktív tüdőbetegség; DOAC = direkt orális antikoaguláns; DVT = mélyvénás trombózis; ECI = ecarinalvadási idő; ERCP = endogén retrográd cholangiopancreatographia; EST $=$ endoszkópos sphincterotomia; GFR = glomeruláris filtrációs ráta; hTI = hígított-trombin-idő; ITO = intenzív terápiás osztály $\mathrm{KVA}=\mathrm{K}$-vitamin-antagonista; $\mathrm{LMWH}=$ alacsony molekulatömegü heparin; $\mathrm{MBI}=$ mitralisbillentyü-elégtelenség; NSAID = nem szteroid gyulladáscsökkentő; $\mathrm{PE}=$ pulmonalis embolia; $\mathrm{PF}=$ pitvarfibrilláció; $\mathrm{TBI}=$ tricuspidalisbillentyü-elégtelenség; $\mathrm{TI}=$ trombinidô

Az elmúlt években négy új, direkt orális antikoaguláns (DOAC) gyógyszer (a direkt trombininhibitor dabigatran etexilát [továbbiakban dabigatran] és a három szelektív Xa véralvadási faktort gátló [rivaroxaban, apixaban, majd az edoxaban]) került hazai forgalomba [1-4]. Ezeknek a DOAC-szereknek az indikációja az ischaemiás stroke és a szisztémás embolisatio prevenciója nonvalvularis pitvarfibrillációban (PF), egy vagy több kockázati tényezővel rendelkező felnőtt betegeknél. További indikáció a mélyvénás trombózis (deep vein thrombosis DVT) és a pulmonalis embolia (PE) kezelése és az ismétlődő DVT és PE megelőzése felnőttekben a heparinok és a hagyományos K-vitamin-antagonista (KVA) gyógyszerek alternatívájaként $[5,6]$. A DOAC-szerek legalább olyan hatékonynak bizonyultak nagy klinikai vizsgálatokban, mint a KVA-gyógyszerek, ugyanakkor számos előnyük mellett kevesebb életveszélyes, súlyos vérzést okoznak, különösen az intracranialis haemorrhagiák tekintetében $[7,8]$. A DOAC-t szedő betegeknél is előfordulhatnak azonban súlyos, életveszélyes, nem kontrollálható vérzések, többnyire gastrointestinalis okok, traumatizáció miatt vagy ritkábban gyógyszer-interakciók, túladagolások következtében. Ezenfelül a DOACkezelést kapó betegeken nemritkán sürgősségi mútétek, azonnali invazív beavatkozások is szükségessé válhatnak. A RE-LY vizsgálatban részt vevő 18113 betegnél 359 esetben (2\%) került sor sürgős mútétre [9]. Ezért a DOAC-szerekkel kapcsolatban is fontos orvosi igény, kívánalom volt ezeknek a gyors sebészeti beavatkozást igénylő, sürgős helyzeteknek a megnyugtató megoldása, rendezése a véralvadásgátlás azonnali felfüggesztésével, iv. antidótum adásával.

A DOAC-gyógyszerek közül elsőként a direkt trombininhibitor dabigatran antidótuma, az idarucizumab került kifejlesztésre, amely specifikusan kötődik a dabigatranhoz és mintegy három perc alatt semlegesíti annak antikoaguláns hatását [10-12]. Ez óriási áttörést jelentett a dabigatrankezelés biztonságosságát illetően [13]. Az idarucizumab egy humanizált, monoklonális, dabigatrant megkötő antitestfragmens, amely a gyógyszer szelektív véralvadásgátló hatását perceken belül teljesen és tartósan felfüggeszti. Az antitestfragmentum kizárólag a szabad dabigatranmolekulákhoz és metabolitjaihoz kötődik, körülbelül 350-szer erősebb affinitással, mint amilyen a dabigatran-trombin kötődés. Az idarucizumab-dabigatran komplexet a nagy stabilitás jellemzi, mivel igen gyors a képződése, de extrém lassú a lebomlási képessége [10-12]. A dabigatran antikoaguláns hatásának a mérésére a hígított-trombin-idő, a trombinidő, az aktivált parciális tromboplasztinidő (APTI) és az ecarin alvadási idő alkalmasak bizonyos megszorításokkal. Az idarucizumab iv. beadása után ezeknek a véralvadási paramétereknek a normális tartományba esô értékei jelzik az antikoaguláns hatás megszűnését [10]. Laboratóriumi vizsgálatok igazolták, hogy az idarucizumab prompt helyreállítja, normalizálja a dabigatran által megnyúlt, említett paramétereket. Klinikai vizsgálatokban az antidótum iv. adása perceken belül, tartósan megszüntette a dabigatran antikoaguláns hatását egészséges önkéntesekben. Hasonló hatást tapasztaltak dabigatrant szedő, életveszélyes vérzéses vagy egyéb akut mútétre váró, sürgős invazív beavatkozásra szoruló betegek túlnyomó többségében. A vizsgálatokban az antidótum iv. beadása után a szabad dabigatran plazmakoncentrációja több mint 90\%-kal csökkent, amely már antikoaguláns hatással nem járt [14].

Az idarucizumabbal végzett RE-VERSE AD klinikai vizsgálat [15] megerősítette az ellenszer kedvező hatásosságát és biztonságosságát. Az eredmények alapján nemrégiben engedélyezték az első DOAC-gyógyszer, a dabigatran iv. antidótumának a forgalomba hozatalát először 2015 októberében az Amerikai Egyesült Államokban, majd 2015 novemberében Európában is. Az új dabigatran-antidótum, az idarucizumab helyét a klinikai gyakorlatban nemrégen Boda [16] ismertette az Orvosi Hetilapban.

Jelen közlemény célja a dabigatran iv. antidótuma, az idarucizumab első hazai alkalmazásának ismertetése egy nonvalvularis paroxysmalis pitvarfibrilláció miatt dabigatrant szedő, akut hasi mútétre, cholecystectomiára szoruló magas stroke-rizikójú, idős nőbetegen.

\section{Esetismertetés}

Egy 79 éves nőbeteg 2016. május 23-án került felvételre a szolnoki Hetényi Géza Kórház-Rendelőintézet Általános Sebészeti Osztályára akut has klinikai tüneteivel. Kórelőzményében hypertonia, COPD, diasztolés szívelégtelenség, kezelt hypothyreosis, méhnyakplasztika, pyelonephritis chronica, osteoporosis, diabetes mellitus, spondylosis universalis, 2007 óta paroxysmalis PF-es epizódok miatti kardiológiai kezelések szerepeltek. 2010ben átmeneti icterusa hátterében epe apró kövességet állapítottak meg. 2012-ben erysipelas miatt kezelték, már akkor észlelték anaemiáját (Hgb: $88 \mathrm{G} / \mathrm{l}$; Htk: $0,27)$, széklet-Weber-vizsgálata negatív lett, hasi ultrahangvizsgálata során tumoros eltérést nem találtak. Echokardiográfiás vizsgálata (2015) balkamra-hypertrophiát, jó szisztolés balkamra-funkciót, tág pitvarokat, II. fokú MBI-t, II-III. fokú TBI-t, magasabb jobb szívfélbeli nyomást véleményezett. A paroxysmalis PF-es 
epizódok miatt low-dose amiodaron (másnaponta 200 mg), valamint kezdetben acenocoumarol, később (2015 óta) dabigatran $(2 \times 110 \mathrm{mg})$ kezelésben részesült (felvételi $\mathrm{CHA}_{2} \mathrm{DS}_{2}$ VASc-pontszám: 6, HAS-BLED pontszám: 4). 2016. februárban a Szolnoki Kórház II. Belgyógyászati Osztályán gyógykezelték cholecystolithiasis, choledocholithiasis okozta görcsös felhasi fájdalmak miatt. 2016. április 19-21. között a Kecskeméti Kórház Gasztroenterológiai Osztályán ERCP, EST, kőextrakció, stentbehelyezés történt, majd további kezelésre visszakerült a küldő szolnoki osztályra (április 21-27.).

Felvétele napján az OMSZ szállította délelőtt (11:40) a sebészeti osztályra egy hete fennálló krónikus jobb oldali felhasi fájdalmak miatt, amelyek a jelentkezése előtt nyolc órával hirtelen jelentősen fokozódtak.

Felvételi státuszából: Közepesen fejlett és táplált. Oedema, icterus, cyanosis nincs. Látható nyálkahártyák közepesen vérteltek, sclera fehér. Mellkas: részarányos, a rekesz mindkét oldalon egyformán tér ki. Pulmo: érdes légzés. Cor: normális nagyságú, 90/min frekvenciájú ritmusos tachycard szívmúködés és pulzus, tiszta szívhangok, zörej nincs. RR: 140/90 Hgmm. Has: kissé meteorisztikus, feszes, nehezen betapintható. Diffúzan kifejezett érzékenység és defense. Renyhe bélhangok. Szabad hasi folyadék nem kopogtatható, májtompulat megtartott. Végtagok: mindkét lábszáron gyógyult fekélyek. Testmagasság: $160 \mathrm{~cm}$, testsúly: $55 \mathrm{~kg}$.

Hasi ultrabangvizsgálat (május 23., 12:25): A máj nem nagyobb, amennyire megítélhető, góc nincs benne. A májkapu és a choledochus nem ítélhető meg. Az intrahepaticus epeutak jelzetten tágabbak. A cholecysta kimenete minimálisan tágabb, folyékony epét nem tartalmaz, a lumenben sưrü, csaknem szolid massza látható és kövek valószínúsíthetők. A pancreasnak csak a corpusa vizsgálható, nem szélesebb, minimálisan durvább szerkezetü. A lép nem nagyobb. A jobb vese környezetétől alig különíthető el, kisebb, körülbelül 7,5 cm-es, parenchymája keskeny. A bal vese korának megfelelő. A hólyagban alig van vizelet. A hasban tágabb, folyadékkal telt vékonybélkacsok láthatók. Vastagabb falú bélkacs nem látszik. A belek között mérsékelt mennyiségú szabad folyadék van. Vélemény: kisfokú intrahepaticus epeúttágulat. Pancreatitis chr. ultrahangjelei. Jobb oldali zsugorvese. Szabad folyadék. Ileus susp.

Aneszteziológiai konzilium (május 23., 14:20): Intratrachealis narkózist tervezünk. Tegnap este a dabigatrant bevette! Opus esetén Praxbind ${ }^{\circledR}(2 \times 2,5 \mathrm{~g} / 50 \mathrm{ml}$ iv. idarucizumab, Boehringer Ingelheim) szükséges! Mai napon gyógyszereit nem vette be! Premedikáció: 1/2 ampulla (120 mg) diaphyllin venosum iv., 1 ampulla $(40 \mathrm{mg})$ omeprazol iv., 1 ampulla (10 mg) metoclopramid iv., 1 ampulla $(10 \mathrm{mg})$ K-vitamin, $500 \mathrm{ml}$ Gelofusin infúzió, $500 \mathrm{ml}$ Ringer-fundin vagy Ringer-laktát infúzió +1 ampulla $(500 \mathrm{mg})$ tranexamicsav.

Mütéti leírás (május 23., 17:00-18:35): Gyulladt, hasüregbe perforált, vérző epehólyag. Cholecystectomia történt a hasüreg kimosásával és drenálással. A mútét során $2 \mathrm{E}$ csoportazonos vvt.-masszát kapott.

Kórlefolyás (május 23. - június 23.): A kezdeti posztoperatív szakban iv. antibiotikus kezelés mellett állapota átmenetileg javult. A negyedik posztoperatív napon hasi fájdalmai fokozódtak. Belgyógyászati, laborvizsgálatok, hasi ultrahangkontroll után szepszis miatt reoperáció, exploratív laparatomia (május 27.) történt, amely zajló akut, diffúz peritonitis képet, nem friss vérzést igazolt. Lavage, drenálás történt, majd a beteg az intenzív terápiás osztályra (ITO-ra) került (május 27.).

Az ITO-n intenzív ápolása, sebkezelése mellett gépi lélegeztetésben, analgoszedációban részesült, antitrombotikus (nadroparin $2 \times 0,4 \mathrm{ml} \mathrm{sc}$.), protonpumpagátló kezelést is kapott, infektológiai konzílium alapján antibiotikus terápiában részesült. Magas kamrai frekvenciájú PF-je miatt iv. amiodaron adására került sor. Május 29én csökkent hemoglobinszintje miatt 2 E választott vvt.massza adása vált szükségessé. Extubálás után a beteg táplálása először parenteralisan, majd gyomorszondán keresztül fokozatosan megtörtént. Június 2-án visszaállított otthoni gyógyszeres kezelése mellett stabil légzéssel és keringéssel, hozzáférhető tudati állapotban került viszszahelyezésre a sebészeti osztályra. Gyógyulását kialakult pneumoniája átmenetileg késleltette, amely antibiotikus kezelésre szanálódott. Június 23-án fokozatos mobilizációja után áthelyezésre került stabil állapotban, javult vesefunkcióval (GFR: $48 \mathrm{ml} / \mathrm{min}$, előzőleg: június 3.: GFR: $26 \mathrm{ml} / \mathrm{min}$ ) a Szolnoki MÁV Kórház Belgyógyászati Osztályára. Az osztályon további mobilizációja során a nadroparinkezelésról visszaállították a dabigatran $(2 \times 110 \mathrm{mg} / \mathrm{nap})$ stroke-prevencióra, később pedig otthonába bocsátották.

\section{Megbeszélés}

A dabigatran antidótumának (idarucizumab) első hazai alkalmazására - a DOAC-gyógyszerek közül elsóként egy nonvalvularis, paroxysmalis PF-es epizódok (magas $\mathrm{CHA}_{2} \mathrm{DS}_{2}$ VASc-pontszám: 6) miatt dabigatrankezelésben $(2 \times 110 \mathrm{mg} / \mathrm{nap})$ részesülő idős nőbeteg esetében került sor, akinek epekövessége kapcsán kialakult akut hasi tünetei miatt halaszthatatlan sebészeti mútétre volt szüksége. A betegnek az aneszteziológiai konzílium mútét előtt idarucizumab adását $(2 \times 2,5 \mathrm{~g} / 50 \mathrm{ml}$ iv. $)$ írta elö, amelyet a beteg szövődménymentesen megkapott a tervezett mütéte előtt körülbelül két órával, az utolsó dabigatranadag bevétele után 20 órával. A hasi mútét során vérző, a hasüregbe perforált gyulladt epehólyagot találtak, csillapíthatatlan vérzés nem volt. A beteg mútét elött 1 ampulla iv. K-vitamint és 1 ampulla tranexamot is kapott. A mütét után $2 \mathrm{E}$ vvt.-massza adására is sor került az eleve ismerten anaemiás idős nőbetegnél. A beteg néhány kiemelt laboratóriumi értékének a kontrollhoz képest bekövetkező változását az idarucizumab javasolt dózisának iv. beadása előtt, majd a hasi mütét után az 1 . táblázatban tüntettük fel. Az idarucizumab beadása 
Néhány kiemelt laboratóriumi paraméter változása az iv. idarucizumab $(2 \times 2,5 \mathrm{~g} / 50 \mathrm{ml}$ iv. $)$ beadása előtt és után

\begin{tabular}{llll}
\hline & $\begin{array}{l}\text { Idarucizumab } \\
\text { beadása előtt }\end{array}$ & $\begin{array}{l}\text { Idarucizumab } \\
\text { beadása után }\end{array}$ & $\begin{array}{l}\text { Laboratóriumi } \\
\text { paraméterek } \\
\text { normálértékei }\end{array}$ \\
\hline Vérvétele ideje & $5.23 .11: 57$ & $5.24 .5: 35$ & $120-160 \mathrm{~g} / 1$ \\
\hline Hemoglobin & 93,70 & 90,10 & $10,36-0,46 \mathrm{l} / 1$ \\
Hematokrit & 0,28 & 0,26 & $4,0-10,0 \mathrm{G} / 1$ \\
Fehérvérsejtszám & 19,70 & 25,00 & $150,0-400,0 \mathrm{G} / 1$ \\
Thrombocytaszám & 464,00 & 361,00 & $0,9-1,3$ \\
INR & 1,88 & 1,87 & $10-17 \mathrm{~s}$ \\
Protrombinidő & 22,00 & 22,00 & $25-43 \mathrm{~s}$ \\
APTI & 50,1 & 42,2 & $2,5-7,5 \mathrm{mmol} / 1$ \\
Karbamid & 17,7 & 17,1 & $40-88 \mu \mathrm{mol} / 1$ \\
Kreatinin & 251,0 & 205,0 & $>90 \mathrm{ml} / \mathrm{min}$ \\
GFR & 15,0 & 19,0 & $<5,0 \mathrm{mg} / 1$ \\
CRP & 149,5 & 200,3 & \\
\hline
\end{tabular}

A dabigatran utolsó adagjának bevétele: 2016.05.22. (19-20 óra között). Az idarucizumab beadása 2016.05.23. 15:00.

A hasi mútét kezdete 17:00. A beteg a hasi mútét után 2 E vvt.-masszatranszfúziót kapott.

APTI = aktivált parciális tromboplasztinidő $\mathrm{CRP}=\mathrm{C}$-reaktív protein; $\mathrm{GFR}=$ glomeruláris filtrációs ráta; $\mathrm{INR}=$ internacionális normalizációs ráció előtti haemostatusvizsgálat fokozott antikoaguláns hatásra (megnyúlt APTI-érték) utalt. Az 1. táblázatból az is kitúnik, hogy az antidótum beadása (május 23., 15 óra) után, másnap reggelre (14 óra múlva) az APTI-érték normalizálódott, másrészt pedig látható, hogy a beteg mútét előtti vesefunkciója jelentősen csökkent volt. Ez utóbbi a főként renalis clearance-û dabigatran eliminációját jelentősen megnyújtja (becsült felezési idő $\geq 20$ óra), plazmakoncentrációját megnöveli. Ebben az esetben, antidótum adása nélkül, a magas operatív vérzési rizikó miatt $\geq 96$ órás dabigatranleállítás javasolt elektív invazív vagy sebészeti beavatkozás előtt $[6,17]$. Esetünkben az akut has miatt a mútét sürgős volt, így ez feltétlenül indokolttá tette az antidótum, az idarucizumab beadását. Az említetteken kívül a vérzési kockázatot tovább növelte az otthoni NSAID (naproxen $2 \times 550 \mathrm{mg} /$ nap) szedése, valamint májfunkciózavarra utaló magasabb INR-értéke $(1,88)$ is. A beteg HASBLED pontszáma (4) is fokozott vérzéses rizikót jelzett [7]. Az ERCP és a hasüregbe perforált vérző epehólyag miatti egy hónappal későbbi akut mútét között összefüggés feltételezhető.

\section{Sürgősségi indikáció}

A dabigatranszedés megerősítése (betegadatok, rokonok, receptek stb.). Ha lehetséges, akkor az antikoaguláció mértékének a meghatározása: az utolsó adag ideje, az APTI és/vagy TI (hTI) meghatározása, vérkép, vesefunkció.

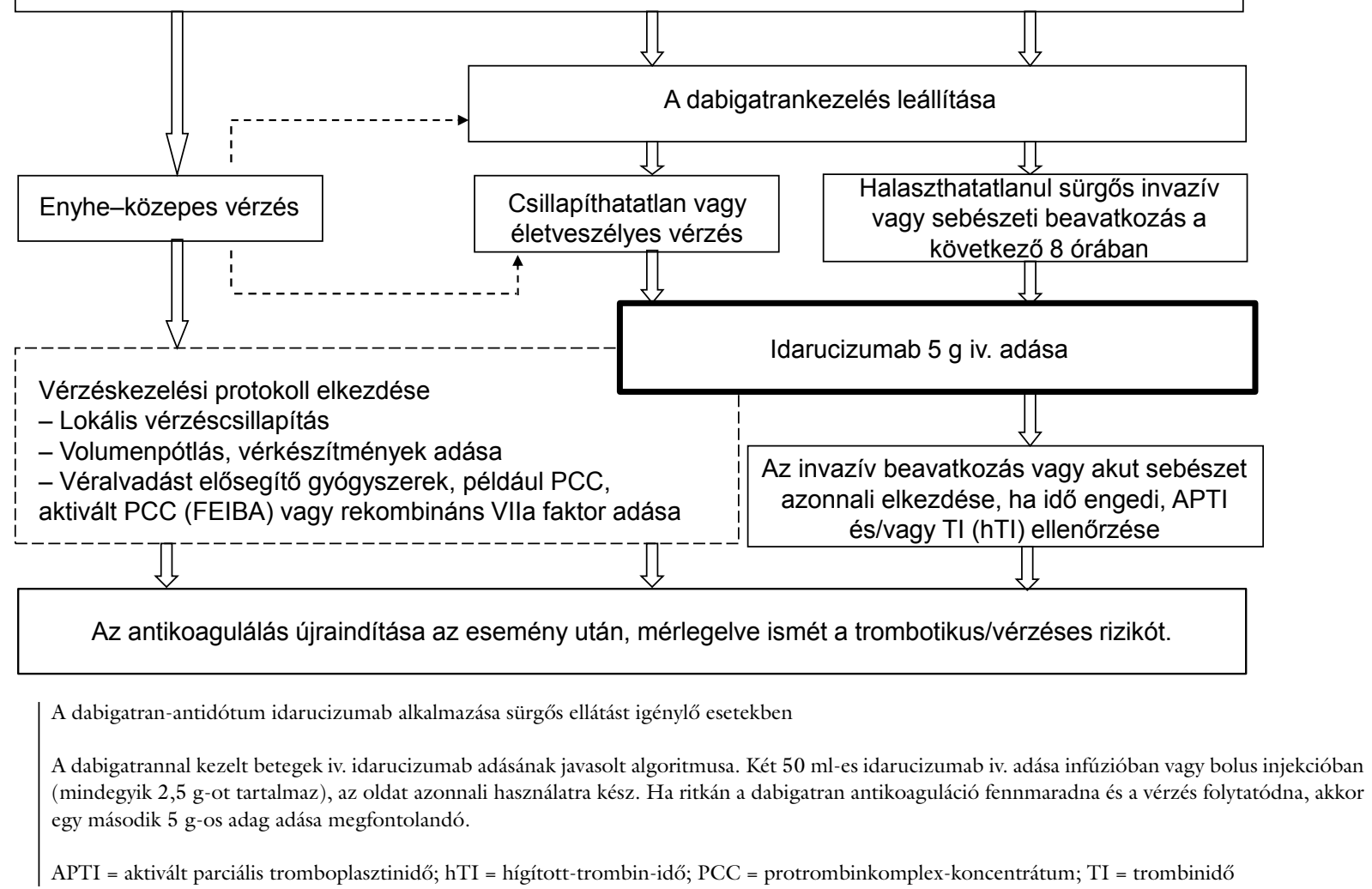


A rutin, jelenlegi gyakorlatban nem áll rendelkezésre megbízható módszer, paraméter a dabigatrannal elért alvadásgátlás intenzitásának a pontos megítélésére a dabigatranvérszinten kívül. Az APTI értéke csak megközelítőleg jelzi az antikoaguláns hatást, a vizsgálatok nem standardizáltak, az eredményeket pedig körültekintéssel kell értékelni [10]. Hasznos lehet a trombinidő (TI), a hígított-trombin-idő (hTI) és az ecarinalvadási idő (ECI) meghatározása is, de ezek sem standardizáltak, az eredményeket szintén körültekintéssel kell fogadni [10, 18]. Az említetteken kívül az antikoaguláns paraméterek nemcsak a mintavétel, hanem az utolsó dabigatrandózis bevételének az időpontjától is függenek. A dabigatran bevételét követően két órával levett vérminta (csúcskoncentrációt jelzi), más, magasabb értéket ad minden alvadási paraméter vizsgálata esetén, mint az ugyanazon adag bevételét 10-16 órával követő vérminta (mélyponti szint) kapcsán [18]. Esetünkben az első vérminta levétele az előző esti dabigatranbevétel után körülbelül 16 órával később történt, amely a mélyponti szintnek felel meg. $\mathrm{Az}$ eleve anaemiás, idős nóbeteg esetében a gyulladt, hasüregbe perforált, vérző epehólyag mütéte kapcsán az antidótumnak is köszönhetően kontrollálhatatlan vérzés nem alakult ki, de a beteg a mütét után transzfúzióra szorult.

Az idarucizumab a direkt trombininhibitor dabigatran specifikus ellenszere. Az antidótum sürgősségi helyzetekben felnőtteknél alkalmazható, amikor a dabigatran hatásának a gyors felfüggesztésére van szükség sürgős mütétek/beavatkozások vagy életveszélyes, csillapíthatatlan vérzések esetén. Az ajánlott dózis $5 \mathrm{~g}$ iv. minden páciens számára, azonnali használatra kész oldatban. Dózismódosításra nincsen szükség, fơként a vesén keresztül ürül, terminális fél életideje 10,3 óra, más gyógyszerekkel nem lép kölcsönhatásba [19]. A dabigatrannal kezelt betegeknél alkalmazott idarucizumab adásának javasolt algoritmusa az 1 . ábrán látható. Klinikai vizsgálatokban (RE-VERSE AD) az idarucizumab iv. adása perceken belül, tartósan felfüggesztette a dabigatran antikoaguláns hatását. Az antikoaguláns hatás felfüggesztése után a betegek 92\%-ánál normális intraoperatív haemostasist értek el, protrombotikus, prokoaguláns hatást nem tapasztaltak. Az idarucizumab iv. beadása után a sürgôs műtét, beavatkozás késedelem nélkül elvégezhetô. Ha a beteg klinikailag stabil, bármikor egyéb antikoaguláns terápia, például LMWH-kezelés is elkezdhető, vagy 24 óra elteltével a dabigatran adása is folytatható a trombotikus/vérzéses rizikó ismételt mérlegelése után. Az idarucizumab igény szerint alkalmazható egyéb, támogató jellegű kezelésekkel együtt. Immunreakciók generálásának alacsony a potenciálja $[14,15,19]$. Az antidótum adása kontraindikált idarucizumaballergia, örökletes fruktózintolerancia (szorbitot tartalmaz a gyógyszer), terhesség vagy szoptatás esetén. Nemrégen számoltak be dabigatrannal kezelt nonvalvularis PF-ben elszenvedett ischaemiás stroke sikeres szisztémás thrombolyticus kezeléséről 5 perccel az iv. antidótum beadása után [20, 21]. Ugyancsak leírták [22] az iv. antidótum sikeres alkalmazását túladagolás esetén egy 68 éves nóbetegen, aki 125 kapszula dabigatrant nyelt le. Nála az eredetileg tervezett hemodialízisre sem volt szükség. (A dabigatran az egyetlen dializálható DOAC-készítmény.)

\section{Következtetés}

Első tapasztalataink szerint a DOAC-szerek közül a dabigatrankezelés egyedülálló biztonságot nyújt azáltal, hogy a speciális antidótuma, az idarucizumab is a kezelöorvos rendelkezésére áll, amely esetünkben is lehetővé tette a sürgős hasi mútét biztonságos elvégzését.

Anyagi támogatás: A kézirat a Boehringer Ingelheim RCV GmbH \& Co KG Magyarországi Fióktelepének támogatásával készült.

Szerzői munkamegosztás: D. L.: Javasolta először az idarucizumab alkalmazását. B. É.: Az anesztéziát végezte. B. I., Sz. Z.: A hasi mútétet végezte. H. Gy.: A beteg osztályos kezelőorvosa volt. B. G.: Az intenzív osztályos kezelő főorvos, valamint ő gyưjtötte össze az adatokat. P. L.: Koordinálás és irodalomgyúités. B. J.: A kórházi adatok begyüjtése, rendszerezése, valamint a kézirat megírása, elkészítése. A kézirat végleges változatát valamennyi szerző elolvasta és jóváhagyta.

Érdekeltségek: P. L.: A Boehringer Ingelheim RCV GmbH \& Co KG Magyarországi Fióktelepének munkatársa. B. J.: A Boehringer Ingelheim RCV GmbH \& Co KG Magyarországi Fióktelepétől előadásokért, kéziratokért alkalmanként honoráriumban részesül.

\section{Köszönetnyilvánítás}

A szerzők köszönetüket fejezik ki a Boehringer Ingelheim GmbH Magyarországi Fióktelepének a kézirat elkészítése során nyújtott támogatásáért.

A publikáció megjelenését a Boehringer Ingelheim támogatta. A cikk a Szerzők véleményét tükrözi, mely eltérhet a Boehringer Ingelheim álláspontjától. Minden megemlített gyógyszer alkalmazásakor az érvényes alkalmazási elő́rás az irányadó.

\section{Irodalom}

[1] Connolly, S. J., Ezekowitz, M. D., Yusuf, S., et al.: Dabigatran versus warfarin in patients with atrial fibrillation. N. Engl. J. Med., 2009, 361(12), 1139-1151.

[2] Patel, M. R., Mahaffey, K. W., Garg, J., et al.: Rivaroxaban versus warfarin in nonvalvular atrial fibrillation. N. Engl. J. Med., 2011, 365(10), 883-891.

[3] Connolly, S. J., Eikelboom, J., Joyner, D., et al.: Apixaban in patients with atrial fibrillation. N. Engl. J. Med., 2011, 364(9), 806-817.

[4] Ruff, C. T., Giugliano, R. P., Antman, E. M., et al.: Evaluation of the novel Xa inhibitor edoxaban compared with warfarin in patients with atrial fibrillation. Design and rationale for the Effec- 
tive aNticoaGulation with factor $\mathrm{xA}$ next GEneration in Atrial Fibrillation-Thrombolysis In Myocardial Infarction study 48 (ENGAGE AF-TIMI 48). Am. Heart J., 2010, 160(4), 635641.e2.

[5] Urooj, F., Kulkarni, A., Stapleton, D., et al.: New oral anticoagulants in nonvalvular atrial fibrillation. Clin. Cardiol., 2016, 39(12), 739-746.

[6] Narisimba, D., Curtis, A. B.: Anticoagulation for atrial fibrillation in the elderly. Arch. Med., 2015, 7(5), 1-12.

[7] Heidbuchel, H., Verhamme, P., Alings, M., et al.: European Heart Rhythm Association Practical Guide on the use of new oral anticoagulants in patients with non-valvular atrial fibrillation. Europace, 2013, 15(5), 625-651.

[8] Grabam, D. J., Reichman, M. E., Wernecke, M., et al.: Stroke, bleeding, and mortality risks in elderly Medicare beneficiaries treated with dabigatran or rivaroxaban for nonvalvular atrial fibrillation. JAMA Intern. Med., 2016, 176(11), 1662-1671.

[9] Healy, J. S., Eikelboom, J., Douketis, J., et al.: Periprocedural bleeding and thromboembolic events with dabigatran compared with warfarin. Circulation, 2012, 126(3), 343-348.

[10] Van Ryn, J., Stangier, J., Haertter, S., et al.: Dabigatran etexilate - a novel, reversible, oral direct thrombin inhibitor: interpretation of coagulation assays and reversal of anticoagulant activity. Thromb. Haemost., 2012, 103(6), 1116-1127.

[11] Pollack, C. V. Jr., Reilly, P. A., Eikelboom, J., et al.: Idarucizumab for dabigatran reversal. N. Engl. J. Med., 2015, 373(6), 511520 .

[12] Eikelboom, J. W., Quinlan, D. J., van Ryn, J., et al.: Idarucizumab the antidote for reversal of dabigatran. Circulation, 2015, 132(25), 2412-2422.

[13] Kiss, R. G.: Direct oral anticoagulants in cardiology. [Direkt orális antikoagulánsok a kardiológiában.] Orv. Hetil., 2016, 157(38), 1507-1510. [Hungarian]

[14] Glund, S., Stangier J., Schmohl, M., et al.: Safety, tolerability and efficacy of idarucizumab for the reversal of the anticoagulant effect of dabigatran in healthy male volunteers: a randomised, pla- cebo-controlled, double-blind phase-1 trial. Lancet, 2015, 386(9994), 680-690.

[15] Pollack, C. V. Jr., Reilly, P. A., Bernstein, R., et al.: Design and rationale for RE-VERSE AD: a phase 3 study of idarucizumab, a specific reversal agent for dabigatran. Thromb. Haemost., 2015, 114(1), 198-205.

[16] Boda, Z.: Treatment with inhibitors of new oral direct anticoagulants in patients with severe bleedings or urgent surgical procedures. The new dabigatran antidote: the place of idarucizumab in clinical practice. [Teendők súlyos vérzés vagy sürgôs sebészeti beavatkozás esetén direkt orális antikoaguláns gyógyszerrel kezeltekben. Az új dabigatran-antidótum: idarucizumab helye a klinikai gyakorlatban.] Orv. Hetil., 2016, 157(12), 443-450. [Hungarian]

[17] Graham, D. J., Reichman, M. E., Wernecke, M., et al.: Cardiovascular, bleeding, and mortality risk in elderly Medicare patients treated with dabigatran or warfarin for nonvalvular atrial fibrillation. Circulation, 2015, 131(2), 157-164.

[18] Pradaxa $^{\circledR}$ (dabigatran etexilát) prescribing guideline. (Felírói útmutató). Boehringer Ingelheim, 2015.

[19] Praxbind ${ }^{\circledast}$ Summary of the product. (Alkalmazási eloórás). Boehringer-Ingelheim, 2016.

[20] Schäfer N., Müller, A., Wüllner, U.: Systemic thrombolysis for ischemic stroke after antagonizing dabigatran with idarucizumab - A case report. J. Stroke Cerebrovasc. Dis., 2016, 25(8), el26el27.

[21] Berrouschot, I., Stoll, A., Hogh, T., et al.: Intravenous thrombolysis with recombinant tissue-type plasminogen activator in a stroke patient receiving dabigatran anticoagulant after antagonization with idarucizumab. Stroke, 2016, 47(7), 1936-1938.

[22] Peetermans, M., Pollack, C. Jv., Reilly, P., et al.: Idarucizumab for dabigatran overdose. Clin. Toxicol., 2016, 54(8), 644-646.

(Borbola József dr., Budapest, Pf. 88, 1450 e-mail: borbola@kardio.hu)

\section{Tisztelt Szerzőink, Olvasóink!}

Az Orvosi Hetilapban megjelenő/megjelent közlemények elérhetőségére több lehetőség kínálkozik.

Rendelhető különlenyomat, melynek áráról bővebben a www.akkrt.hu honlapon (Folyóirat Szerzőknek, Különlenyomat menüpont alatt) vagy Szerkesztöségünkben tájékozódhatnak.

A közlemények megvásárolhatók pdf-formátumban is, illetve igényelhetö Optional Open Article (www.oopenart.com).

Adott dij ellenében az online közlemények bárki számára hozzáférhetök honlapunkon (a közlemények külön linket kapnak, igy más oldalról is linkelhetővé válnak).

Bővebb információ a hirdetes@akkrt.hu címen vagy különlenyomat rendelése esetén a Szerkesztőségtöl kérhető. 